\title{
Vaginal Verrucous Carcinoma
}

National Cancer Institute

\section{Source}

National Cancer Institute. Vaginal Verrucous Carcinoma. NCI Thesaurus. Code C6325.

A squamous cell carcinoma that arises from the vagina and is characterized by a papillary growth pattern, acanthotic epithelium with minimal or absent atypia, and pushing borders. 